\title{
DASAR HUKUM PENATAAN LEMBAGA NEGARA YANG TIDAK DIATUR UNDANG-UNDANG DASAR NEGARA REPUBLIK INDONESIA TAHUN 1945
}

\author{
Yudi Widagdo Harimurti \\ Fakultas Hukum Universitas Trunojoyo Madura \\ J1. Raya Telang Po. Box. 2 Kamal - Bangkalan 69162 \\ E-mail : wiedharimurti@gmail.com
}

\begin{abstract}
This study aims to explain the occurrence of various types of rules as the legal basis for regulating state institutions that are not regulated by the 1945 Constitution of the Republic of Indonesia and the types of rules that are appropriate for the legal basis for regulating state institutions that are not regulated by the 1945 Constitution. The study shows that the problems in structuring state institutions are due to the absence of a common legal basis for state institutions that are not regulated by the 1945 Constitution of the Republic of Indonesia. The types of rules that are appropriate as the legal basis for regulating state institutions that are not regulated by the 1945 Constitution of the Republic of Indonesia are the laws.
\end{abstract}

Keywords: Arrangement, State Institution, Legal Basis, 1945 Constitution of the Republic of Indonesia.

\begin{abstract}
Abstrak: Kajian ini bertujuan untuk menjelaskan terjadinya berbagai jenis peraturan

perundang-undangan sebagai dasar hukum pengaturan lembaga negara yang tidak diatur oleh UUD NRI Tahun 1945 serta jenis peraturan perundangundangan yang tepat untuk dasar hukum pengaturan lembaga negara yang tidak diatur oleh UUD NRI Tahun 1945. Hasil kajian menunjukkan bahwa permasalahan dalam penataan lembaga negara dikarenakan tidak adanya kesamaan dasar hukum untuk lembaga negara yang tidak diatur oleh UUD NRI Tahun 1945. Jenis peraturan perundang-undangan yang tepat sebagai dasar hukum pengaturan lembaga negara yang tidak diatur UUD NRI Tahun 1945 adalah undang-undang.
\end{abstract}

Kata Kunci : Penataan, Lembaga Negara, Dasar Hukum, UUD NRI Tahun 1945.

\section{PENDAHULUAN}

Eksistensi negara sebagaimana lazimnya membutuhkan penyelenggara negara untuk mencapai cita-cita dan mewujudkan tujuan bernegara. Penyelenggara negara dimaksud adalah pemerintah yang berdaulat. Dalam hal ini negara atau pemerintah membutuhkan alat-alat perlengkapan negara atau organ negara atau lembaga negara. Pemerintah (yang memerintah) bertindak atas nama negara dan menyelenggarakan kekuasaan dari negara tersebut serta tetap harus mendapat persetujuan dari yang diperintah (rakyat).

Alat-alat perlengkapan negara atau organ negara atau lembaga negara umumnya merepresentasikan "kekuasaan legislatif, kekuasaan eksekutif, kekuasaan yudikatif' (Manan, 2012:8). Untuk menyamakan persepsi dalam artikel ini istilah alat-alat perlengkapan negara atau organ negara atau lembaga negara adalah lembaga negara. Hal itu didasarkan pada pendapat Padmo Wahjono, bahwa lembaga negara ialah "alat-alat perlengkapan negara pada suatu negara yang mempunyai peranan dasar dalam kegiatan kenegaraan" (Wahjono, 1984:17). Jimly Asshiddiqie menyatakan, bahwa lembaga negara adalah "lembaga apa saja yang dibentuk bukan sebagai lembaga masyarakat" (Asshiddiqie, 2006 : 33). 
pembagian kekuasaan-kekuasaan dan persaingan antar kekuasaan-kekuasaan tersebut dalam suatu negara. Menurutnya negara merupakan suatu struktur administrasi atau organisasi yang konkrit dan membatasi pengertian negara semata-mata sebagai paksaan fisik yang digunakan untuk memaksakan ketaatan. Pendapat Max Weber tersebut menyiratkan eksistensi lembaga-lembaga negara dalam suatu negara adalah untuk merealisasikan kekuasaankekuasaan negara.

Pengertian lembaga negara menurut Jellinek (Hakim, 2010:27) dibagi menjadi dua, yaitu lembaga negara yang langsung (mittelbare organ) dan lembaga negara yang tidak langsung (unmittelbare organ). Lembaga negara yang langsung (mittelbare organ) adalah lembaga negara yang ada di dalam Konstitusi atau Undang-Undang Dasar. Lembaga negara yang tidak langsung (unmittelbare organ) adalah lembaga negara yang keberadaannya tergantung pada lembaga negara langsung.

Konstitusi sebagai condition sine qua non sebuah negara tidak saja merupakan kontrak sosial melainkan juga memberikan gambaran tentang mekanisme penyelenggaraan negara oleh lembaga-lembaga negara (Safiudin, 2018). Konstitusi Negara Indonesia (UndangUndang Dasar Negara Republik Indonesia Tahun 1945 setelah perubahan) mengatur dan menetapkan bahwa lembaga negara yang langsung (mittelbare organ) ada 34 organ atau lembaga negara (Awaliyah, 2011:121). Beberapa lembaga negara tersebut diantaranya: Majelis Permusyawaratan Rakyat, Presiden \& Wakil Presiden, duta \& konsul, dewan pertimbangan, Kementerian Negara, Pemerintahan Daerah, Dewan Perwakilan Rakyat, Dewan Perwakilan Daerah, Komisi Pemilihan Umum, Bank Sentral, Badan Pemeriksa Keuangan (BPK), Mahkamah Agung (MA), Komisi Yudisial (KY), Mahkamah Konstitusi (MK), Tentara Nasional Indonesia (TNI), dan Kepolisian Negara Republik Indonesia (POLRI).

Lembaga negara yang tidak langsung (unmittelbare organ) dapat diartikan sebagai lembaga negara yang tidak diatur oleh UUD NRI Tahun 1945. Berarti keberadaan lembaga negara yang tidak diatur oleh UUD NRI Tahun 1945 tergantung pada lembaga negara yang diatur dan ditetapkan oleh UUD NRI Tahun 1945 dengan kata lain lembaga negara yang tidak diatur oleh UUD NRI Tahun 1945 merupakan lembaga negara pendukung terhadap lembaga negara yang diatur dan ditetapkan oleh UUD NRI Tahun 1945. Dalam berbagai kepustakaan, lembaga negara yang tidak diatur oleh Konstitusi atau UUD ada yang menyatakan sebagai lembaga negara independen atau "state auxiliary bodies atau independent regulatory agencies atau independent regulatory commissions" (Milakovich \& Gordon, 2001:432 \& 443).

Praktek ketatanegaraan Indonesia telah memunculkan sejumlah lembaga negara yang tidak diatur oleh UUD NRI Tahun 1945 dengan berbagai jenis peraturan perundang-undangan sebagai dasar hukum. Hal tersebut berarti membutuhkan penataan, supaya benar dan tepat jenis peraturan perundang-undangan sebagai dasar hukum pengaturan lembaga negara yang tidak diatur oleh UUD NRI Tahun 1945. Dasar hukum pengaturan sejumlah lembaga negara yang tidak diatur oleh UUD NRI Tahun 1945 dengan berbagai jenis peraturan perundangan, yakni ada yang diatur dengan Undang-Undang, ada yang diatur dengan Peraturan Pemerintah, ada yang dengan Keputusan Presiden atau ada yang dengan Peraturan Presiden.

Berdasarkan penjelasan di atas maka menarik untuk dilakukan sebuah kajian mengenai terjadinya berbagai jenis peraturan perundang-undangan sebagai dasar hukum pengaturan lembaga negara yang tidak diatur oleh UUD NRI Tahun 1945 serta jenis peraturan perundang-undangan yang tepat untuk dasar hukum pengaturan lembaga negara yang tidak diatur oleh UUD NRI Tahun 1945. 


\section{HASIL DAN PEMBAHASAN}

\section{Berbagai Jenis Peraturan Perundang- Undangan sebagai Dasar Hukum Pengaturan Lembaga Negara yang Tidak Diatur UUD NRI Tahun 1945}

Dalam penyelenggaraan negara, kekuasaan negara harus dibatasi mengingat Indonesia adalah negara hukum. Pembatasan terhadap kekuasan negara atau dengan kata lain pembatasan terhadap lembaga-lembaga negara yang merupakan perwujudan nyata kekuasaan negara. Lembaga negaralah yang melaksanakan kekuasaan-kekuasaan negara atau lebih tepat kekuasaan pejabat yang menjalankan lembaga-lembaga negara.

Pembatasan kekuasaan harus dilakukan untuk menghindari timbulnya kesewenangwenangan pemerintah terhadap rakyat. Harus diingat, bahwa eksistensi pemerintah dalam menjalankan kekuasaan negara ialah atas amanah dan untuk rakyat.

Kepentingan rakyat harus diutamakan, sehingga pemerintah harus selalu mendengarkan dan mengakomodir aspirasi dan kebutuhan rakyat. Oleh sebab itu pemerintah harus menjamin kebebasan bagi rakyat untuk menyampaikan aspirasi dan partisipasi dalam rangka penyelenggaran negara.

Pemerintahan dalam menjalankan kekuasaan-kekuasaan negara membutuhkan lembaga negara. Di dalam Sistem Ketatanegaraan Republik Indonesia belum ada pengertian lembaga negara, baik itu lembaga negara yang diatur oleh UUD NRI Tahun 1945 maupun lembaga negara yang tidak diatur oleh UUD NRI Tahun 1945. Selain itu juga belum jelas, jenis apakah yang dikategorikan sebagai lembaga negara yang diatur oleh UUD NRI Tahun 1945 maupun sebagai lembaga negara yang tidak diatur oleh UUD NRI Tahun 1945. Lebih lanjut mestinya dibutuhkan juga peraturan tentang lembaga negara, syarat-syarat pembentukan lembaga negara, mekanisme menentukan dan memilih anggota dan bagaimanakah pertanggung jawaban dilaksanakan.

Eksistensi lembaga negara yang tidak diatur oleh UUD NRI Tahun 1945 perlu kepastian dan kejelasan dasar hukum dalam kerangka Sistem Ketatanegaraan Republik Indonesia. Pembentukan lembaga negara selalu terkait dengan sistem ketatanegaraan suatu negara, "yang didalamnya termuat antara lain fungsi-fungsi dari setiap lembaga negara yang dibentuk" (Hakim 2009:44). Hal tersebut diperkuat oleh pendapat Sri Soemantri, bahwa "lembaga negara harus membentuk suatu kesatuan proses yang satu sama lain saling berhubungan dalam rangka penyelenggaraan fungsi negara atau actual governmental process" (Sri Soemantri, 1986:33). Berarti harus ada koordinasi dan kerjasama diantara lembaga negara yang diatur oleh UUD NRI Tahun 1945 dengan lembaga negara yang tidak diatur oleh UUD NRI Tahun 1945.Selanjutnya pembahasan mengenai jenis peraturan perundangan-undangan yang menjadi dasar hukum pengaturan lembaga negara yang tidak diatur oleh UUD NRI Tahun 1945. Untuk lebih memudahkan dalam pembahasan dijabarkan dalam bentuk tabel secara berurutan, mulai dari dasar hukum UU sampai dengan dasar hukum Perpres. Tabel mengenai lembaga negara yang tidak diatur oleh UUD NRI Tahun 1945 dengan dasar hukum UU, sebagaimana tersaji pada tabel 1. 
Tabel 1. Lembaga Negara Yang Tidak Diatur UUD NRI Tahun 1945 dengan Dasar Hukum UU

\begin{tabular}{|c|c|c|}
\hline No. & Nama Lembaga Negara & Dasar Hukum \\
\hline 1. & Dewan Koperasi Indonesia (DEKOPIN) & UU Nomor 25 Tahun 1992 \\
\hline 2. & Badan Tenaga Nuklir Nasional (BATAN) & UU Nomor 10 Tahun 1997 \\
\hline 3. & Badan Pusat Statistik (BPS) & UU Nomor 16 Tahun 1997 \\
\hline 4. & Komisi Pengawas Persaingan Usaha (KPPU) & UU Nomor 5 Tahun 1999 \\
\hline 5. & Badan Perlindungan Konsumen Nasional (BPKN) & UU Nomor 8 Tahun 1999 \\
\hline 6. & Komisi Nasional Hak Asasi Manusia (KOMNASHAM) & UU Nomor 39 Tahun 1999 \\
\hline 7. & Dewan Pers & UU Nomor 40 Tahun 1999 \\
\hline 8. & Komisi Kepolisian Nasional (KOMPOLNAS) & UU Nomor 2 Tahun 2002 \\
\hline 9. & Dewan Pertahanan Nasional (WANTANAS) & UU Nomor 3 Tahun 2002 \\
\hline 10. & Komisi Perlindungan Anak Indonesia (KPAI) & UU Nomor 23 Tahun 2002 \\
\hline 11. & Komisi Pemberantasan Tindak Pidana Korupsi (KPK) & UU Nomor 30 Tahun 2002 \\
\hline 12. & Komisi Penyiaran Indonesia (KPI) & UU Nomor 32 Tahun 2002 \\
\hline 13. & Dewan Pengupahan & UIU Nomor 13 Tahun 2003 \\
\hline 14. & Badan Nasional Sertifikasi Profesi (BNSP) & U Nomor 15 lanun 2003 \\
\hline 15. & Komisi Kejaksaan Republik Indonesia (KK) & UU Nomor 16 Tahun 2004 \\
\hline 16. & Lembaga Penjamin Simpanan (LPS) & $\begin{array}{l}\text { UU Nomor } 24 \text { Tahun } 2004 \text { jo. } \\
\text { UU Nomor } 7 \text { Tahun } 2009\end{array}$ \\
\hline 17. & Konsil Kedokteran Indonesia (KKI) & UU Nomor 29 Tahun 2004 \\
\hline 18. & $\begin{array}{l}\text { Badan Nasional Penempatan dan Perlindungan Tenaga Kerja } \\
\text { Indonesia (BNP2TKI) }\end{array}$ & UU Nomor 39 Tahun 2004 \\
\hline 19. & Dewan Jaminan Sosial Nasional (DJSN) & UU Nomor 40 Tahun 2004 \\
\hline 20. & Lembaga Perlindungan Saksi dan Korban (LPSK) & $\begin{array}{l}\text { UU Nomor } 13 \text { Tahun } 2006 \text { jo. } \\
\text { UU Nomor } 31 \text { Tahun } 2014\end{array}$ \\
\hline 21. & Badan Nasional Penanggulangan Bencana (BNPB) & UU Nomor 24 Tahun 2007 \\
\hline 22. & Badan Koordinasi Penanaman Modal (BKPM) & UU Nomor 25 Tahun 2007 \\
\hline 23. & Dewan Energi Nasional (DEN) & UU Nomor 30 Tahun 2007 \\
\hline 24. & Perpustakaan Nasional Republik Indonesia (PERPUSNAS) & UU Nomor 43 Tahun 2007 \\
\hline 25. & Komisi Pengawas Haji Indonesia (KPHI) & $\begin{array}{l}\text { UU Nomor } 13 \text { Tahun } 2008 \text { jo. } \\
\text { UU Nomor } 34 \text { Tahun } 2009\end{array}$ \\
\hline 26. & Komisi Informasi Pusat (KIP) & UU Nomor 14 Tahun 2008 \\
\hline 27. & Komite Nasional Keselamatan Transportasi (KNKT) & UU Nomor 17 Tahun 2008 \\
\hline 28. & Ombudsman Republik Indonesia (ORI) & UU Nomor 37 Tahun 2008 \\
\hline 29. & Badan Nasional Penanggulangan Terorisme (BNPT) & UU Nomor 43 Tahun 2008 \\
\hline 30. & Dewan Gelar, Tanda Jasa dan Tanda Kehormatan (Dewan GTK) & UU Nomor 20 Tahun 2009 \\
\hline 31. & Lembaga Sensor Film (LSF) & UU Nomor 33 Tahun 2009 \\
\hline 32. & Badan Narkotika Nasional (BNN) & UU Nomor 35 Tahun 2009 \\
\hline 33. & Arsip Nasional Republik Indonesia (ANRI) & UU Nomor 43 Tahun 2009 \\
\hline 34. & Badan Kependudukan dan Keluarga Berencana Nasional (BKKBN) & UU Nomor 52 Tahun 2009 \\
\hline 35. & Pusat Pelaporan dan Analisis Transaksi Keuangan (PPATK) & \\
\hline 36. & $\begin{array}{l}\text { Komite Koordinasi Nasional Pencegahan dan Pemerantasan } \\
\text { Tindak Pidana Pencucian Uang (Komite TPPU) }\end{array}$ & UU Nomor 8 Tahun 2010 \\
\hline 37. & Badan Informasi Geospasial (BIG) & UU Nomor 4 Tahun 2011 \\
\hline 38. & Badan Koordinasi Pemberantasan Rupiah Palsu (BOTASUPAL) & UU Nomor 7 Tahun 2011 \\
\hline $\begin{array}{l}39 . \\
40\end{array}$ & $\begin{array}{l}\text { Dewan Kehormatan Penyelenggara Pemilu (DKPP) } \\
\text { Badan Pengawas Pemilu (BAWASLU) }\end{array}$ & UU Nomor 15 Tahun 2011 \\
\hline 41. & Badan Intelijen Negara (BIN) & UU Nomor 17 Tahun 2011 \\
\hline 42. & Otoritas Jasa Keuangan (OJK) & UU Nomor 21 Tahun 2011 \\
\hline 43. & Badan Kepegawaian Negara (BKN) & \\
\hline 44. & Lembaga Administrasi Negara (LAN) & UU Nomor 5 Tahun 2014 \\
\hline 45. & Komisi Aparatur Sipil Negara (KASN) & \\
\hline 46. & Dewan Pertimbangan Otonomi Daerah (DPOD) & UU Nomor 23 Tahun 2014 \\
\hline 47. & Badan Keamanan Laut (BAKAMLA) & UU Nomor 32 Tahun 2014 \\
\hline
\end{tabular}


Daftar lembaga negara yang tidak diatur oleh UUD NRI Tahun 1945 dengan

dasar hukum Peraturan Pemerintah disajikan dalam tabel 2.

Tabel 2. Lembaga Negara Yang Tidak Diatur UUD NRI Tahun 1945 Dengan Dasar Hukum PP

\begin{tabular}{cll}
\hline No. & \multicolumn{1}{c}{ Nama Lembaga Negara } & \multicolumn{1}{c}{ Dasar Hukum } \\
\hline 1. & Dewan Ketahanan Pangan (DKP) & PP Nomor 68 Tahun 2002 \\
2. & Badan SAR Nasional (BASARNAS) & PP Nomor 36 Tahun 2006 \\
\hline
\end{tabular}

Tabel berikut adalah tabel mengenai daftar lembaga negara yang tidak diatur oleh UUD NRI Tahun 1945 dengan dasar hukum Keppres. Daftar lembaga negara tersebut dengan dasar hukum Keppres, yakni tersaji pada Tabel 3 pada halaman berikut.

Tabel 3. Lembaga Negara Yang Tidak Diatur Oleh UUD NRI Tahun 1945 DenganDasar Hukum Keppres

\begin{tabular}{|c|c|c|}
\hline No. & Nama Lembaga Negara & Dasar Hukum \\
\hline 1. & $\begin{array}{l}\text { Komite Olah Raga Nasional Indonesia } \\
\text { (KONI) }\end{array}$ & Keppres Nomor 72 Tahun 2001 \\
\hline 2. & $\begin{array}{l}\text { Badan Pengawasan Obat dan Makanan } \\
\text { (BPOM) }\end{array}$ & $\begin{array}{l}\text { Keppres Nomor } 103 \text { Tahun } 2001 \text { jo. Perpres } \\
\text { Nomor } 3 \text { Tahun } 2013 \\
\text { Keppres Nomor } 110 \text { Tahun } 2001 \text { jo. Perpres } \\
\text { Nomor } 4 \text { Tahun } 2013\end{array}$ \\
\hline 3. & $\begin{array}{l}\text { Badan Pengawas Tenaga Nuklir } \\
\text { (BAPETEN) }\end{array}$ & $\begin{array}{l}\text { Keppres Nomor } 103 \text { Tahun } 2001 \text { jo. Perpres } \\
\text { Nomor } 3 \text { Tahun } 2013 \\
\text { Keppres Nomor } 110 \text { Tahun } 2001 \text { jo. Perpres } \\
\text { Nomor } 4 \text { Tahun } 2013\end{array}$ \\
\hline 4. & Badan Standarisasi Nasional (BSN) & $\begin{array}{l}\text { Keppres Nomor } 103 \text { Tahun } 2001 \text { jo. Perpres } \\
\text { Nomor } 3 \text { Tahun } 2013 \\
\text { Keppres Nomor } 110 \text { Tahun } 2001 \text { jo. Perpres } \\
\text { Nomor } 4 \text { Tahun } 2013\end{array}$ \\
\hline 5. & $\begin{array}{l}\text { Lembaga Ilmu Pengetahuan Indonesia } \\
\text { (LIPI) }\end{array}$ & $\begin{array}{l}\text { Keppres Nomor } 103 \text { Tahun } 2001 \text { jo. Perpres } \\
\text { Nomor } 3 \text { Tahun } 2013 \\
\text { Keppres Nomor } 110 \text { Tahun } 2001 \text { jo. Perpres } \\
\text { Nomor } 4 \text { Tahun } 2013\end{array}$ \\
\hline 6. & $\begin{array}{l}\text { Lembaga Penerbangan dan Antariksa } \\
\text { Nasional (LAPAN) }\end{array}$ & $\begin{array}{l}\text { Keppres Nomor } 103 \text { Tahun } 2001 \text { jo. Perpres } \\
\text { Nomor } 3 \text { Tahun } 2013 \\
\text { Keppres Nomor } 110 \text { Tahun } 2001 \text { jo. Perpres } \\
\text { Nomor } 4 \text { Tahun } 2013\end{array}$ \\
\hline 7. & Lembaga Sandi Negara (LEMSANNEG) & $\begin{array}{l}\text { Keppres Nomor } 103 \text { Tahun } 2001 \text { jo. Perpres } \\
\text { Nomor } 3 \text { Tahun } 2013 \\
\text { Keppres Nomor } 110 \text { Tahun } 2001 \text { jo. Perpres } \\
\text { Nomor } 4 \text { Tahun } 2013\end{array}$ \\
\hline 8. & Dewan Kelautan Indonesia (DEKIN) & Keppres Nomor 21 Tahun 2007 \\
\hline 9. & $\begin{array}{l}\text { Badan Koordinasi Penataan Ruang } \\
\text { Nasional (BKPRN) }\end{array}$ & Keppres Nomor 4 Tahun 2009 \\
\hline 10. & $\begin{array}{l}\text { Dewan Teknologi Informasi dan } \\
\text { Komunikasi Nasional (DETIKNAS) }\end{array}$ & Keppres Nomor 1 Tahun 2014 \\
\hline
\end{tabular}

Penjelasan selanjutnya mengenai lembaga negara yang tidak diatur oleh UUD NRI Tahun 1945 dengan dasar hukum Perpres. Seperti penjelasan yang lain, maka berikut ditampilkan dalam bentuk

tabel. Tabel 4 memaparkan mengenai daftar lembaga negara yang tidak diatur oleh UUD NRI Tahun 1945 dengan dasar hukum Perpres. Adapun secara lengkap daftar lembaga negara tersebut dengan 
dasar hukum Perpres sebagaimana disajikan tabel 4. Tabel 4. Lembaga Negara Yang Tidak

\begin{tabular}{cll}
\hline No. & Nama Lembaga Negara & Dasar Hukum \\
\hline 1. & $\begin{array}{l}\text { Komisi Nasional Anti Kekerasan Terhadap } \\
\text { Perempuan (KOMNAS Perempuan) }\end{array}$ & Perpres Nomor 65 Tahun 2005 \\
\hline 2. & $\begin{array}{l}\text { Lembaga Ketahanan Nasional } \\
\text { (LEMHANNAS) }\end{array}$ & Perpres Nomor 67 Tahun 2006 \\
\hline 3. & $\begin{array}{l}\text { Lembaga Kebijakan Pengadaan Barang/ } \\
\text { Jasa Pemerintah (LKPP) }\end{array}$ & Perpres Nomor 106 Tahun 2007 \\
\hline 4. & Dewan Nasional Perubahan Iklim (DNPI) & Perpres Nomor 46 Tahun 2008 \\
\hline 5. & $\begin{array}{l}\text { Badan Metereologi, Klimatologi dan } \\
\text { Geofisika (BMKG) }\end{array}$ & Perpres Nomor 61 Tahun 2008 \\
\hline & $\begin{array}{l}\text { Dewan Nasional dan Dewan Kawasan } \\
\text { Kawasan Ekonomi Khusus (Dewan }\end{array}$ & $\begin{array}{l}\text { Perpres Nomor 33 Tahun 2010 jis. } \\
\text { Perpres Nomor 124 Tahun 2012, Nomor 150 Tahun 2014 }\end{array}$ \\
\hline 7. & $\begin{array}{l}\text { Basanan Nasional Penanggulangan Terorisme } \\
\text { (BNPT) }\end{array}$ & $\begin{array}{l}\text { Perpres Nomor 46 Tahun 2010 jo. } \\
\text { Perpres Nomor 12 Tahun 2012 }\end{array}$ \\
\hline 8. & $\begin{array}{l}\text { Badan Pengawasan Keuangan dan } \\
\text { Pembangunan (BPKP) }\end{array}$ & Perpres Nomor 192 Tahun 2014 \\
\hline 9. & Badan Ekonomi Kreatif(BEK) & Perpres Nomor 6 Tahun 2015 \\
\hline 10. & Kantor Staf Presiden (KSP) & Perpres Nomor 26 Tahun 2015 \\
\hline 11. & Badan Restorasi Gambut (BRG) & Perpres Nomor 1 Tahun 2016 \\
\hline 12. & $\begin{array}{l}\text { Komite Ekonomi Industri Nasional } \\
\text { (KEIN) }\end{array}$ & Perpres Nomor 8 Tahun 2016 \\
\hline
\end{tabular}

Tabel 1 sampai dengan Tabel 4, sebagaimana tersebut di atas tersirat beberapa hal mengenai dasar hukum lembaga negara yang tidak diatur oleh UUD NRI Tahun 1945. Selain sebagaimana yang tersaji pada Tabel 5 di atas, diketemukan juga kejanggalan dasar hukum pengaturan lembaga negara yang tidak diatur oleh UUD NRI Tahun 1945. Kejanggalan-kejanggalan tersebut adalah (a) sebuah UU mengatur 3 (tiga) lembaga negara sekaligus dengan 3 (tiga) bentuk lembaga negara yang berbeda yaitu : BKN, LAN dan KASN, (b) Sebuah UU mengatur 2 (dua) lembaga negara yang tidak diatur oleh UUD NRI Tahun 1945 sekaligus dengan 2 (dua) bentuk lembaga negara yang berbeda yaitu Dewan Pengupahan dan BNSP;
Diatur UUD NRI Tahun 1945 dengan Dasar Hukum Perpres

PPATK dan Komite TPPU, (c) UU Nomor 7 Tahun 2017 tentang Pemilihan Umum, yang di dalamnya mengatur 2 (dua) lembaga negara yakni : DKPP dan BAWASLU, (d) Ada 2 (dua) Keppres dan 2 (dua) Perpres mengatur 6 (enam) lembaga negara yang tidak diatur oleh UUD NRI Tahun 1945 sekaligus dengan 2 (dua) bentuk lembaga negara yang berbeda, yaitu berbentuk badan dan berbentuk lembaga. Keenam lembaga negara dengan 2 (dua) bentuk yang berbeda tersebut adalah BPOM, BAPETEN, BSN, LIPI, LAPAN dan LEMSANNEG. Untuk lebih mudah memahami beberapa hal dan kejanggalan tersebut adalah seperti tergambarkan pada Tabel 5. 
Tabel 5. Kejanggalan Mengenai Lembaga Negara yang Tidak Diatur oleh UUD NRI Tahun 1945

\begin{tabular}{|c|c|c|}
\hline No. & $\begin{array}{c}\text { Lembaga Negara Yang Tidak Diatur } \\
\text { Oleh UUD NRI Tahun } 1945\end{array}$ & Jumlah \\
\hline \multirow{10}{*}{1.} & \multicolumn{2}{|l|}{ Bentuk Lembaga Negara } \\
\hline & a. Dewan & 14 \\
\hline & Badan & 26 \\
\hline & Lembaga & 9 \\
\hline & Komisi & 11 \\
\hline & \multicolumn{2}{|l|}{ Bentuk lainnya } \\
\hline & a. Konsil, Pusat, Otoritas dan Kantor & 4 \\
\hline & Komite & 4 \\
\hline & Langsung Nama Lembaga Negara & 3 \\
\hline & Jumlah & 71 \\
\hline \multirow{6}{*}{2.} & Dasar Hukum & \\
\hline & a. UU & 47 \\
\hline & $\mathrm{PP}$ & 2 \\
\hline & Keppres & 10 \\
\hline & Perpres & 12 \\
\hline \multirow{2}{*}{\multicolumn{2}{|c|}{$\begin{array}{l}\text { Jumlah } \\
\text { Lembaga Negara Dengan Dasar Hukum Yang Sama, yakni } \\
\text { dengan UU }\end{array}$}} & 71 \\
\hline & & 9 \\
\hline 4. & $\begin{array}{l}\text { Lembaga Negara Dengan Dasar Hukum Yang Sama, yakni } \\
\text { dengan Keppres dan Perpres }\end{array}$ & 6 \\
\hline
\end{tabular}

Jenis Peraturan Perundang-Undangan yang Tepat sebagai Dasar Hukum Pengaturan Lembaga Negara yang Tidak diatur UUD NRI Tahun 1945

Dengan memahami berbagai jenis peraturan perundang-undangan sebagai dasar hukum pengaturan lembaga negara yang tidak diatur oleh UUD NRI Tahun 1945, sebagaimana pada uraian sebelumnya menunjukkan kepada kita, bahwa pemberian jenis peraturan perundang-undangan sebagai dasar hukum pengaturan terhadap lembaga negara yang tidak diatur oleh UUD NRI Tahun 1945 dalam praktek ketatanegaraan Indonesia tidak konsisten. Berarti dibutuhkan penataan terhadap jenis peraturan perundangundangan sebagai dasar hukum pengaturan lembaga negara yang tidak diatur oleh UUD NRI Tahun 1945 dalam arti jenis peraturan perundangan-undangan yang benar dan tepat.

Eksistensi lembaga negara yang tidak diatur oleh UUD NRI Tahun 1945 harus ada kepastian jenis peraturan perundang- undangan sebagai dasar hukum pengaturan lembaga negara tersebut dalam kerangka Sistem Ketatanegaraan Republik Indonesia. Pada akhirnya nanti diharapkan dalam perspektif kehidupan bernegara, eksistensi lembaga negara yang tidak diatur oleh UUD NRI Tahun 1945 harus memiliki kepastian jenis peraturan perundang-undangan sebagai dasar hukum pengaturan lembaga-lembaga negara tersebut.

Selain itu, juga tidak ada peraturan perundang-undangan yang mengatur dan menetapkan tentang jenis peraturan perundang-undangan yang menjadi dasar hukum keberadaan lembaga negara tersebut. Hal itu berakibat tidak ada kepastian hukum dan juga berakibat tidak konsisten jenis peraturan perundang-undangan yang dijadikan sebagai dasar hukum pengaturan lembaga negara yang tidak diatur oleh UUD NRI Tahun 1945.

Lembaga negara yang diatur oleh UUD NRI Tahun 1945, dasar hukum 
pengaturannya pasti dan jelas oleh UUD NRI Tahun 1945. Apabila dipahami, bahwa eksistensi lembaga negara yang tidak diatur oleh UUD NRI Tahun 1945 tergantung pada lembaga negara yang diatur dan ditetapkan oleh UUD NRI Tahun 1945 maka secara gelede normstelling dasar hukum pengaturan lembaga negara yang tidak diatur oleh UUD NRI Tahun 1945 adalah oleh UU. Selain secara gelede normstelling, bahwa dasar hukum yang benar dan tepat untuk eksistensi lembaga negara yang tidak diatur oleh UUD NRI Tahun 1945 adalah UU, mengingat juga UU itu adalah jenis peraturan perundang-undangan yang dibentuk oleh DPR dengan persetujuan bersama Presiden. Menurut Hans Kelsen dan Hans Nawiasky, UU dipandang sebagai derivasi konstitusi yang tidak bisa dipisahkan dari konstitusi tersebut (Sudirman, 2016).

Pengertian alinea di atas semakin mempertegas, bahwa dasar hukum pengaturan lembaga negara yang tidak diatur oleh UUD NRI Tahun 1945 yang benar dan tepat harus dengan UU. Dengan demikian penyelenggara negara dan pemerintahan khususnya Presiden tidak dengan mudah dan dengan kehendak politiknya membentuk dan membubarkan lembaga negara yang tidak diatur oleh UUD NRI Tahun 1945 tersebut. Tentu saja akan berbeda, jika dasar hukum eksistensi lembaga negara yang tidak diatur oleh UUD NRI Tahun 1945 tidak dengan UU.

Sebagai perbandingan mengenai pengaturan lembaga negara di negara lain adalah pengaturan lembaga negara di Negara Malaysia dan di Negara Amerika Serikat. Pemilihan Negara Malaysia, mengingat sistem pemerintahan Malaysia berbeda dengan sistem pemerintahan Negara Indonesia. Sedangkan pemilihan Negara AS, bahwa sistem pemerintahan Negara AS hampir sama dengan sistem pemerintahan Negara Indonesia.

Sebelum penjelasan lebih lanjut, mengenai pengaturan lembaga negara di Negara Malaysia dan di Negara AS, perlu disampaikan terlebih dahulu mengenai hierarki peraturan perundang-undangan yang ada kedua negara tersebut. Dari hierarki peraturan perundang-undangan akan diketahui bagaimanakah dasar hukum pengaturan lembaga negara dalam arti apakah dasar hukum pengaturan oleh Konstitusi/ UUD, apakah dasar hukum pengaturan juga oleh UU, apakah dasar hukum

pengaturan juga dengan jenis peraturan perundang-undangan selain UU. Akan diketahui apakah terdapat mittelbare organ dan unmittelbare organ. Sebagaimana diuraikan pada halaman sebelumnya, fokus penulisan artikel ini pada unmittelbare organ.

Hierarki peraturan perundang-undangan di Negara Malaysia yaitu (a) Konstitusi Federal Malaysia, yang (selanjutnya disingkat KFM), (b) Akta (c) Enakmen, (d) Perundangan Kecil. Hierarki peraturan perundang-undangan di Negara AS adalah (a) Konstitusi Federal Amerika Serikat, yang (selanjutnya disingkat KFAS), (b) UndangUndang yang (selanjutnya disingkat UU), (c) Perjanjian.

Perbandingan hierarki peraturan perundang-undangan yang ada di beberapa negara disajikan dalam tabel 6 .

Tabel 6. Perbandingan Hierarki Peraturan Perundang-undangan di Negara Malaysia, di Negara AS dan di Negara Indonesia

\begin{tabular}{clll}
\hline No. & $\begin{array}{l}\text { N e g a r a } \\
\text { Malaysia }\end{array}$ & Negara AS & $\begin{array}{l}\text { Negara } \\
\text { Indonesia }\end{array}$ \\
\hline 1. & KFM & KFAS & UUD NRI \\
2. & Akta & UU & Tahun 1945 \\
3. & Enakmen & Perjanjian & UU/Perpu \\
4 & Perundangan & & PP \\
& Kecil & & Perpres \\
& & & $\begin{array}{l}\text { Perda } \\
\text { Provinsi }\end{array}$ \\
& & & Perda \\
& & & Kabupaten/ \\
& & & Kota
\end{tabular}

Dasar hukum pengaturan lembaga negara di Negara Malaysia oleh 2 (dua) jenis peraturan perundang-undangan, yakni KFM dan Akta. KFM selain mengatur kekuasaan negara secara umum, juga memberikan dasar dalam pembentukan lembaga negara di 
Negara Malaysia. Adapun lembaga-lembaga negara yang diatur dalam KFM ialah secara berurutan (JC. Fong, 2008:253) adalah (a) Majlis Raja-raja (b) Badan Eksekutif (c) Badan Perundang-undangan (d) Badan Kehakiman (e) Majlis Tanah Negara (f) Majlis Keuangan Negara (g) Majlis Angkatan Tentara (h) Suruhanjaya (Suruhanjaya Pilihan Raya, Suruhanjaya Perkhidmatan Kehakiman dan Perundangan, Suruhanjaya Perkhidmatan Awam, Suruhanjaya Pasukan Polis, Suruhanjaya Perkhidmatan Pendidikan).

Khusus lembaga negara yang berbentuk Suruhanjaya, selain diatur oleh KFM masih harus diatur lagi oleh Akta. Selain yang diatur dalam KFM, ada Suruhanjaya yang langsung diatur oleh Akta. Suruhanjaya itu Suruhanjaya Hak Asasi Manusia (Faruqi, 2008:389-418) yang diatur oleh Akta 597 tentang Suruhanjaya Hak Asasi Manusia.

Sementara pengaturan lembaga negara di Negara AS sangat berbeda dengan di Negara Malaysia. KFAS tidak mengatur lembaga negara, KFAS lebih menekankan pada pembagian kekuasaan negara kedalam 3 (tiga) macam kekuasaan, yaitu: kekuasaan legislatif, kekuasaan eksekutif dan kekuasaan yudisial. Selain itu KFAS mengatur tentang hak, kewenangan dan prosedur secara umum ketiga macam kekuasaan negara tersebut. Lembaga negara yang mendukung dalam penyelenggaraan negara diatur dalam peraturan perundang-undangan di luar KFAS.

Pembentukan lembaga negara yang mendukung penyelenggaraan negara merupakan kewenangan Presiden. Lembaga negara umumnya berbentuk dewan atau berbentuk komisi. Lembaga negara yang berbentuk dewan mempunyai kedudukan yang lebih tinggi daripada lembaga negara yang berbentuk komisi. Lembaga negara berbentuk dewan merupakan bagian dari pelaksanaan kekuasaan eksekutif. Beberapa lembaga negara berbentuk dewan tersebut: Dewan Penasehat Ekonomi, Dewan Kualitas Lingkungan dan Dewan Keamanan Nasional.

Lembaga negara yang berbentuk komisi biasanya merupakan lembaga negara independen, lembaga negara yang membantu penyelenggaraan negara. Lembaga negara berbentuk komisi tersebut, diantaranya ialah Komisi Perdagangan Federal sebagaimana yang diatur dalam UU tentang Komisi Perdagangan Federal Tahun 1914. Disamping itu masih ada komisi lain, yakni Komisi Keamanan Produk Konsumen yang dibentuk berdasarkan UU tentang Keamanan Produk Konsumen Tahun 1972.

Setelah mengetahui dasar hukum pengaturan lembaga negara di Negara Malaysia dan di Negara AS, berikutnya dilakukan perbandingan dasar hukum pengaturan lembaga negara pendukung kedua negara tersebut dengan dasar hukum pengaturan lembaga negara pendukung di Negara Indonesia. Agar lebih mudah memahami perbandingan dasar hukum pengaturan lembaga negara pendukung, baik dasar hukum pengaturan di Negara Malaysia, dasar hukum pengaturan di Negara AS maupun dasar hukum pengaturan lembaga negara pendukung di Negara Indonesia disajikan dalam tabel 7.

Tabel 7. Perbandingan Pengaturan Lembaga Negara Pendukung di Negara Malaysia, di Negara AS dan Di Negara Indonesia

\begin{tabular}{llll}
\hline $\begin{array}{l}\text { Lembaga Negara } \\
\text { Pendukung }\end{array}$ & Malaysia & AS & Indonesia \\
\cline { 1 - 2 } Suruhanjaya & Akta & UU & Undang- \\
\cline { 1 - 1 } Dewan & & & Undang \\
Komisi & & & $\begin{array}{l}\text { PP } \\
\text { Perpres }\end{array}$ \\
\hline Dewan & & Keppres \\
Badan & & \\
Lembaga & & & \\
Komisi & & \\
Bentuk Lainnya & & & \\
\hline
\end{tabular}

Dari perbandingan pengaturan lembaga negara pendukung, sebagaimana tabel di atas, maka benar dan tepat bahwa dasar hukum pengaturan lembaga negara pendukung (lembaga negara yang tidak diatur oleh Konstitusi/UUD) dengan UU (Harimurti, 2016:319). Memperkuat hal tersebut secara gelede normstelling berdasarkan hierarki peraturan perundang-undangan, terdapat lembaga negara yang diatur oleh Konstitusi/ 
UUD, maka lembaga negara yang tidak diatur oleh Konstitusi/UUD dengan UU. Semakin benar dan tepat, bahwa dasar

\section{SIMPULAN}

UUD NRI 1945 sebagai tertib hukum tertinggi salah satunya mengatur tentang kedudukan lembaga Negara sebagai penyelenggara Negara. Namun apabila dilihat secara mendalam, didalam UUD NRI 1945 tidak kesemuanya mengatur tentang lembaga negara secara keseluruhan. Hal ini menyebabkan munculnya banyak peraturan perundang-perundangan baik berupa Undang-undang, Peraturan Pemerintah, Peraturan Presiden, dan Keputusan Presiden sebagai dasar hukum pengaturan lembaga

\section{DAFTAR RUJUKAN}

Asshiddiqie, Jimly. 2006. Perkembangan dan Konsolidasi Lembaga Negara Pasca Reformasi. Jakarta : Sekretariat Jenderal dan Kepaniteraan Mahkamah Konstitusi RI.

Awaliyah, Siti. 2011. Sistem Ketatanegaraan Republik Indonesia Berdasarkan Pancasila dan UUD 1945. Jurnal Pendidikan Pancasila dan Kewarganegaraan. Volume 24. No.2. Malang.

Faruqi, Shad Saleem. 2008. Document of Destiny - The Constitution of the Federation of Malaysia. Selangor: Star Publications.

Hakim, Lukman. 2009. Eksistensi KomisiKomisi Negara Dalam Sistem Ketatanegaraan Republik Indonesia. Disertasi. Malang: Program Studi Doktor Ilmu Hukum Fakultas Hukum Universitas Brawijaya.

Hakim, Lukman. 2010. Kedudukan Hukum Komisi Negara Di Indonesia. Malang: Program Pascasarjana Universitas Brawijaya

Harimurti, Yudi Widagdo. 2016. Politik Hukum Keberadaan Lembaga Negara Yang Tidak Diatur Dalam UndangUndang Dasar Negara Republik hukum pengaturan lembaga negara yang tidak diatur oleh UUD NRI Tahun 1945 dengan UU.

negara yang tidak diatur oleh UUD NRI Tahun 1945 sehingga memunculkan sebuah ketidakpastian hukum terhadap pengaturan lembaga negara yang tidak diatur oleh UUD NRI Tahun 1945 karena dasar hukum yang berbeda-beda. Jenis peraturan perundangundangan yang tepat sebagai dasar hukum pengaturan lembaga negara yang tidak diatur UUD NRI Tahun 1945 yaitu satu peraturan perundang-undangan berupa undang-undang.

Indonesia Tahun 1945 (Suatu Analisis Evaluatif)". Disertasi. Malang : Program Studi Doktor Ilmu Hukum Fakultas Hukum Universitas Brawijaya.

JC. Fong. 2008 Constitutional Federalism in Malaysia. Selangor: Sweet \& Maxwell Asia

Manan, Bagir. 2012. Membedah UUD 1945. Malang : UB Press.

Milakovich, Michael E. \& Gordon, George J. 2001. Public Administration in America. USA: Wadsworth \& Thomson Learning, Seventh Edition.

Safiudin, Achmad, dkk. 2018. Urgensitas Mahkamah Konstitusi Mengeluarkan Fatwa Hukum dalam Pembentukan Undang-Undang. Jurnal Ilmiah Pendidikan Pancasila dan Kewarganegaraan. (Online), Volume 3, Nomor 2, Halaman 113-125, Desember 2018 (http://journal2.um.ac.id/index. php/jppk/article/view/7812/3744, diakses pada 17 April 2019)

Soemantri, Sri. 1986. Tentang LembagaLembaga Negara Menurut UUD 1945. Bandung : Alumni.

Sudirman. 2016. Memurnikan Kewenangan Mahkamah Konstitusi sebagai Lembaga Pengawal Konstitusi. Jurnal 
Ilmiah Pendidikan Pancasila dan Kewarganegaraan. (Online), Volume 1, Nomor 1, Halaman 48-55, Juni 2016 (http://journal2.um.ac.id/index.php/ jppk/article/view/347/230, diakses pada 5 Maret 2019)

Weber, Max Teori Kelembagaan (online), http://www.teorikelembagaannegaram enurutparaahli-definisidanpengertian, diunduh tanggal 10 Januari 2017. Max Weber menyatakan mengenai ciri negara, yakni "berbagai struktur yang mempunyai fungsi yang berbeda, seperi jabatan dan lembaga yang memiliki tugas berdasarkan kewenangannya". Wahjono, Padmo. 1984. Beberapa Masalah Ketatanegaraan Di Indonesia. Jakarta CV. Rajawali 